\title{
小児の鼻アレルギーと気管支喘息について
}

\author{
鵜飼幸太郎* ・坂倉 康夫* ・伊藤由紀子* ・浜口 富美* \\ 三吉 康郎*·吉住 完**・内田 幸憲 ${ }^{* *}$
}

\section{Nose of Bronchial Asthma and Allergic Rhinitis in Pediatric Patients}

\author{
Kotaro Ukai, Yasuo Sakakura, Yukiko Itoh, Fumi Sakata, Yasuro Miyoshi \\ (Department of Otolaryngology, Mie University School of Medicine) \\ Tamotsu Yoshizumi and Yukinori Uchida \\ (Department of Pediatrics, Mie National Hospital)
}

This study was undertaken to ascertain whether nasal laboratory findings in asthmatic patients without nasal symptoms could be different from those in nasal allergic patients.

Sixty-five patients between the ages of 5 and 18 years with extrinsic asthma (asthma group) were investigated by nasal symptoms, signs, and other laboratory findings. These results were compared with those obtained in the 71 patients of nasal allergy to house dust (nasal allergy group).

1. The mean value of $\mathrm{FEV}_{1}$ in the asthma group was $67.9 \% \pm 22.0$.

2. The skin test reaction to house dust was positive in $90.8 \%$ of the asthma group.

3. The nasal provocative test to house dust was positive in $67.7 \%$ of the asthma group.

4. Eosinophils in nasal secretions were abnormally increased in $44.6 \%$ of the asthma group.

5. In the asthma group, $30.8 \%$ had asthma alone, $9.2 \%$ had asthma with atopic dermatitis, $40 \%$ had asthma with allergic rhinitis, and $20 \%$ had asthma with atopic dermatitis and allergic rhinitis.

6. Maxillary sinusitis was found in $40 \%$ of the asthma group by nasal X-ray examination.

7. Neutrophils in nasal secretion were increased abnormally in $53.1 \%$ of the asthma group.

8. The mean value of eosinophils in the blood was $800.8 / \mathrm{mm}^{3} \pm 559.4(\mathrm{n}=62)$ in the asthma group, and $616 / \mathrm{mm}^{3} \pm 400(\mathrm{n}=66)$ in the nasal allergy group. There was a statistically significant difference between both groups $(\mathrm{P}<0.001)$.

9. The mean values of serum $\mathrm{IgE}$ were $2474.8 \mathrm{IU} / \mathrm{ml} \pm 2640(\mathrm{n}=61)$ in the asthma group and $569.6 \mathrm{IU} / \mathrm{ml} \pm 670.5(\mathrm{n}=66)$ in the nasal allergy group. There was a 
statistically significant difference between both groups $(\mathrm{P}<0.001)$.

10. The dilution test of the skin reaction and the RAST SCORE showed similar patterns in both groups.

11. There was a similar correlation in the nasal signs of both groups. On the other hand, there was a converse correlation in the nasal symptoms of both groups.

12. It was supposed that the difference in nasal symptoms in both groups might come from the difference of nasal mucosal reactivity or a concentration of histamine released from basophilic cells.

\section{は じめに}

気管支喘息患者に鼻アレルギーを合併する割合は 50 ～ $80 \%{ }^{1) ~ 6)}$ と舅アレルギー患者における喘息

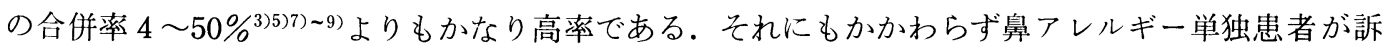
えるよらな鼻症状を訴えることは非常に少ないように思える。このことは同じ量の抗原が鼻内に入 っても鼻アレルギー単独群の場合には鼻症状を現わすが，喘息群においては症状を現わさないの か，あるいは両群とも同程度の症状があるが喘息群の場合には下気道の症状が鼻症状より強いため に自覚しないだけなのか，あるいは鼻症状を訴えないのは鼻アレルギーを合併していないのか，そ れとも他の理由によるのか興味あるところである.

著者等はこれらの疑問点を解明する為に, 小児喘息患者の鼻症状や鼻内局所所見, 臨床検查所見 等を小児鼻アレルギー単独患者のそれと比較検討を加えてみた.

\section{対象と方法}

研究対象は国立三重病院小児医療センターで アトピー型又は混合型気管支喘息と診断された 入院患者 36 名と外来通院患者 29 名の合計 65 名で ある．対照群として昭和53年の 1 月から12月ま での 1 年間に三重大耳鼻科アレルギー外来を受 診した15才までのハウスダスト鼻アレルギー患 者で喘息の合併や既往のない71名を選び，これ ら症例の治療開始前のパラメーターを喘息群の それと比較検討した。検査は問診による鼻症 状, 前鼻鏡検査, 鼻汁中好酸球及び好中球検 查, 下鼻甲介粘膜誘発試験, 鼻部レ線検查, 血 中好酸球数, 皮内反応閾值試験, 血清 $\operatorname{IgE}$ 值, RAST SCORE, 肺機能検査等を行った. 鼻の 自覚症状, 鼻粘膜所見, 鼻粘膜誘発反応の程度 は奥田の分類(10)を用いた。鼻症状及び鼻局所所 見については，全体の程度をより簡単に表現す るため, 鼻症状では, くしゃみ発作, 擤鼻回 数, 鼻閉の程度につきH以上に 1 点を与え, こ れらの合計点で現わした。同様に鼻粘膜所見に
ついても下甲介粘膜の腫脹, 色調, 水性分泌量 について井以上に 1 点を与え，これらの合計点 で現わした。鼻汁中の好酸球や好中球検査で は，サランラップに採取した鼻汁を Hansel 液 で染色後1000倍の視野で検鏡し 4 個以下を (一), 5 〜20個を(+), 21〜100個を(H), 101個 以上を（H）として分類した。末梢血中好酸球 は血液像より好酸球 100 分率を求めた. 1 元拡散 法による血清 $\operatorname{IgE}$ 濃度の測定にはトリパルチ ゲン（ヘキスト）を用いた. RAST SCOREの 測定には RAST シオノギを用いた。鼻部レ線 検査はWaters 法により上顎洞の陰影の強さで 4 段階に分類した。即ち（一）は全く陰影のな いもの，（十）は軽度陰影のあるもの，（H）は 全体に渡りびまん性に混濁しているもの，(H) は（十）と（H）の中間のものである.肺機能 検査では閉塞性肺疾患の代表的検査である 1 秒 率について検討を加えた。 


\section{研 究 結 果}

年令別分布：喘息群では 5 才から18才までに わたり 9 才にピークがみられた。 ハウスダスト

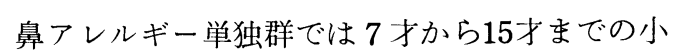
児で12才に最も多く分布していた（図 1 ）.

1 秒率 : 肺機能検查の弓ち閉塞性肺疾患の代 表的検査である 1 秒率は喘息群で $67.9 \% \pm 22.0$ $(\mathrm{n}=65)$ と正常値の $80 \%$ に比べ著るしく低值を 示した。

皮内反応陽性抗原 : 喘息患者の皮内反応によ る抗原陽性率はハウスダストが $90.8 \%$ と最も多 く, 次いでパスパート $78.5 \%$, ブロンカスマ $52.3 \%$ の順であった. 又ほとんどの症例で $2 つ$ 以上の抗原が陽性であった（図 2 ).

鼻汁中好酸球数: 喘息群62例中 (十) は 32.3 $\%$, (H)は $9.2 \%$, (H)は3.1\%で44.6\%が1000 倍の視野で 5 個以上の好酸球を認めた（図 3 ).

鼻粘膜誘発試験：喘息群の全症例に対しハウ スダストによる鼻粘膜誘発試験を試みたとこ ろ, (十) が32.3\%, (H) が $21.0 \%$, (H) が $14.5 \%$ で67.7\%が陽性であった（図 4 ）.

症例分布: 皮内反応, 鼻汁中好酸球, 鼻粘膜 誘発試験, 既往歴等から喘息群65例の症例を検 討してみると図 5 に示す如くである．即ち喘息 単独は $30.8 \%$, 喘息にアトピー性皮膚炎を合併 したもの $9.2 \%$ ，喘息に鼻アレルギーを合併し たもの $40 \%$ ，喘息に鼻アレルギーとアトピー性 皮膚炎を合併したもの $20 \%$ あっった，以上の結 果から喘息に鼻アレルギーを合併する症例は全 体の60\%でこのらちのほとんどの症例はハウス ダストが原因抗原と考えられた.

鼻部レ線所見：喘息群40例のレ線写真の結果 を図 6 に示した。 Waters 法で上顎洞に両侧と も全く陰影を認めなかった（一）はわずか $5 \%$, 両側の上顎洞がびをん性に混濁を認めた（师） は40\%と最も多く, 軽度の陰影を認めた（十） は30\%，その中間の（H）は27.5\%であった.

鼻汁中好中球数：喘息患者64例の鼻汁中好中 球数は図 7 に示した。中等度以上即ち 1000 倍の
視野で20個以上の好中球を認めたのは $53.1 \%$ で あった. 又好中球増多を示した鼻汁中には多数 の細菌を検出した。



図 1 年令別分布

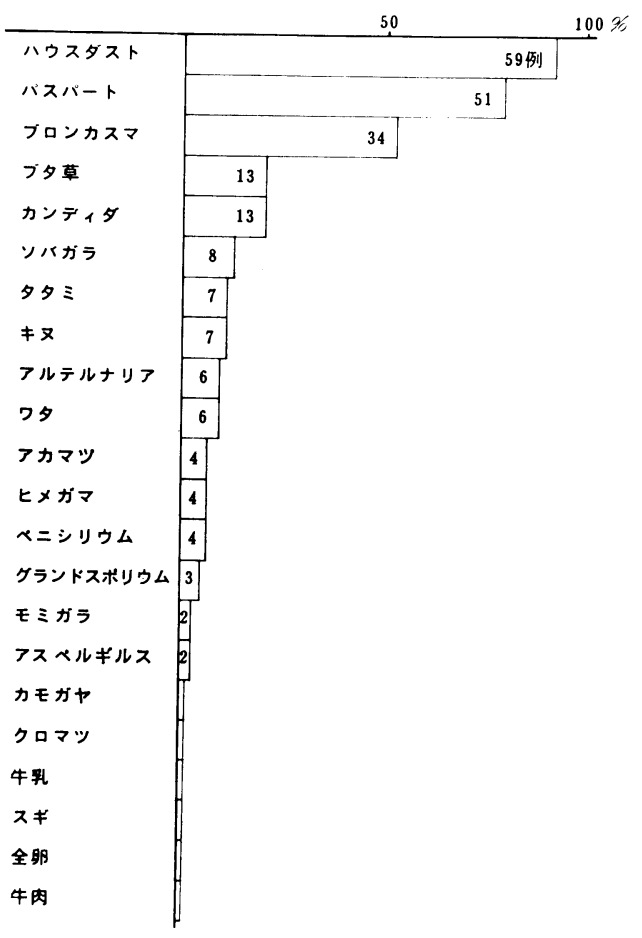

図 2 喘息群皮内反応陽性抗原 


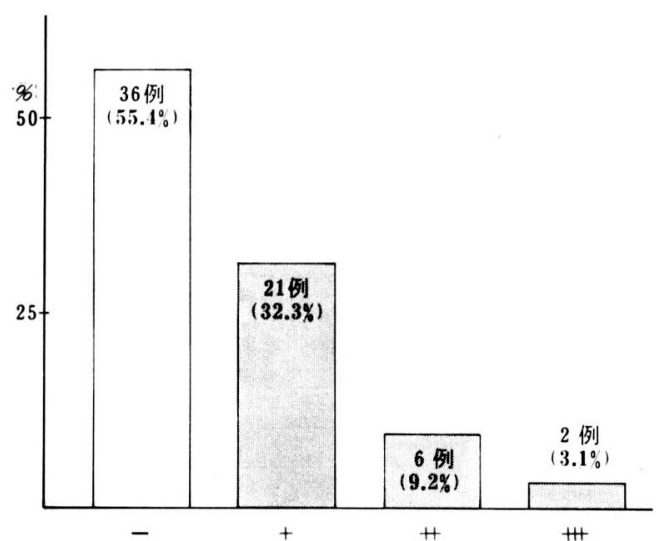

図 3 喘息群鼻汁中好酸球数

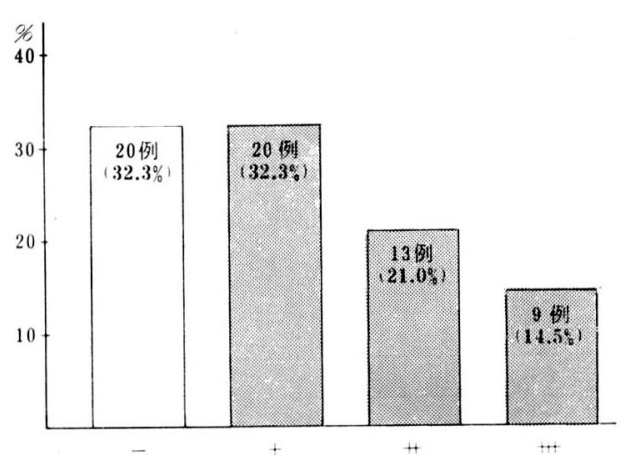

図 4 喘息群ハウスダスト鼻粘膜誘発試験

皮内反応閾值：ハウスダストに対し皮内反応 陽性の喘息群59例中皮内反応閾值試験を試みた 47例をハウスダスト鼻アレルギー単独群の65例 と比較してみた。喘息群の方は 1 万倍で $66 \%$, 10万倍で $29.8 \%$ であったが, 鼻アレルギー単独 群では1000倍で $33.8 \% ， 1$ 万倍で $49.2 \%$ と幾分 鼻アレルギー群の方が高い閾值を示した（図 8 ).

血中好酸球数 : 喘息群は $800.8 / \mathrm{mm}^{3} \pm 559.4$ $(\mathrm{n}=62)$ で鼻アレルギー単独群 $616 / \mathrm{mm}^{3} \pm 400$ $(\mathrm{n}=60)$ と統計的に有意差が認められた（p< $0.05)$.

血清 $\operatorname{IgE}$ 值 : 図 9 に示すごとく, 喘息群では $2474.8 \mathrm{IU} / \mathrm{ml} \pm 2640(\mathrm{n}=61)$ であるのに対し 鼻アレルギー単独群では $569.6 \mathrm{IU} / \mathrm{ml} \pm 670.5$

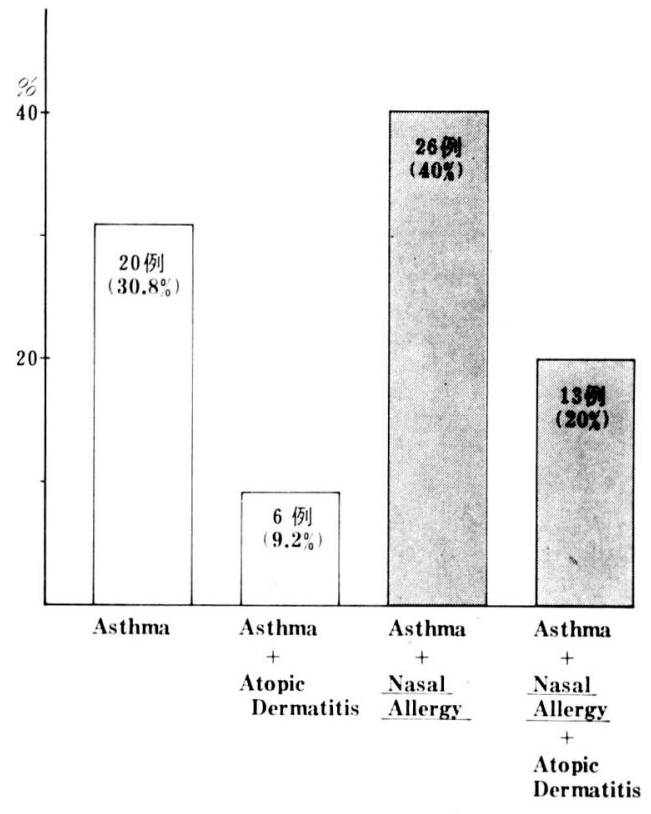

図 5 喘息群症例分布

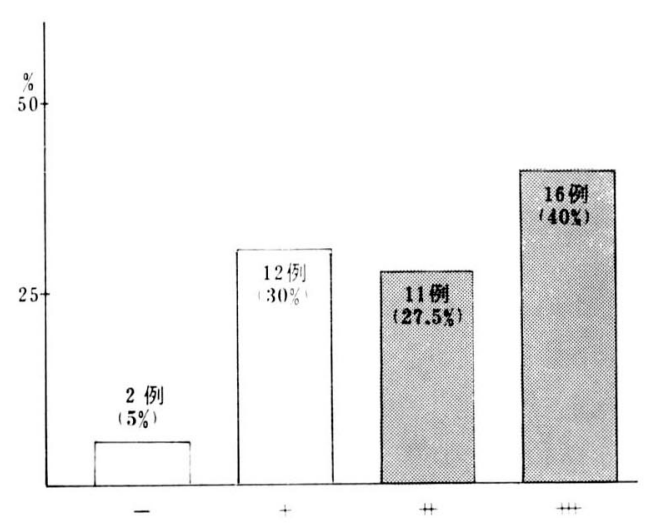

図 6 喘息群鼻部レ線所見

（n=66）と喘息群が著るしく高値を示した。そ してこれらの間には統計的に有意差を認めた $(\mathrm{p}<0.001)$.

RAST SCORE : ダニに対する RAST SCO$\mathrm{RE}$ は両群ともほぼ同様の傾向を示し SCORE 3 が喘息群 $66.7 \%$, 鼻アレルギー群 $53.4 \%$ と最 も多く認めた（図10）.

鼻内局所所見及び鼻症状 : 図11に示す如く鼻 内局所所見では喘息群, 鼻アレルギー群共に 2 


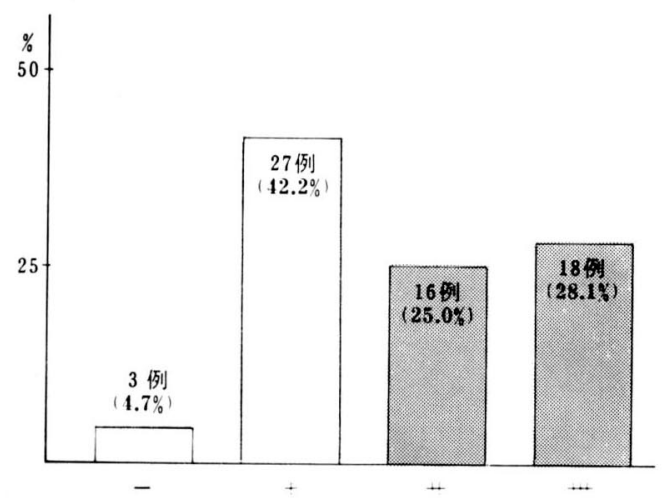

図 7 喘息群鼻汁中好中球数

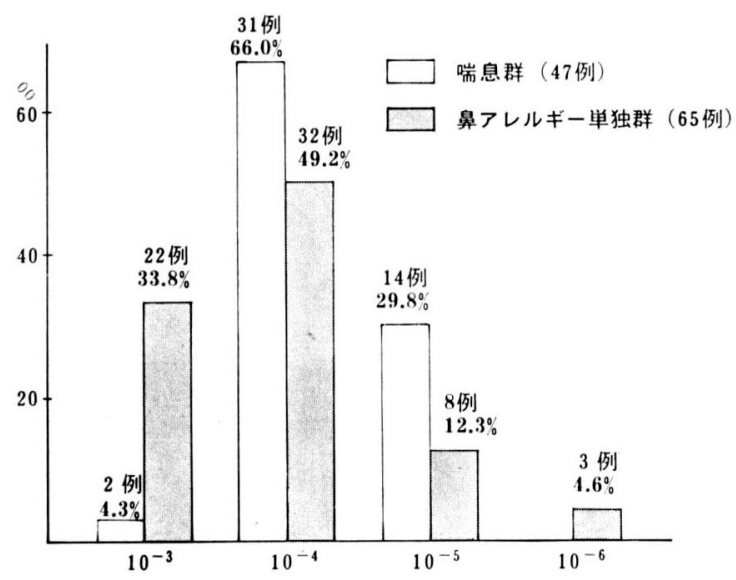

図 8 ハウスダスト皮内反応閾值

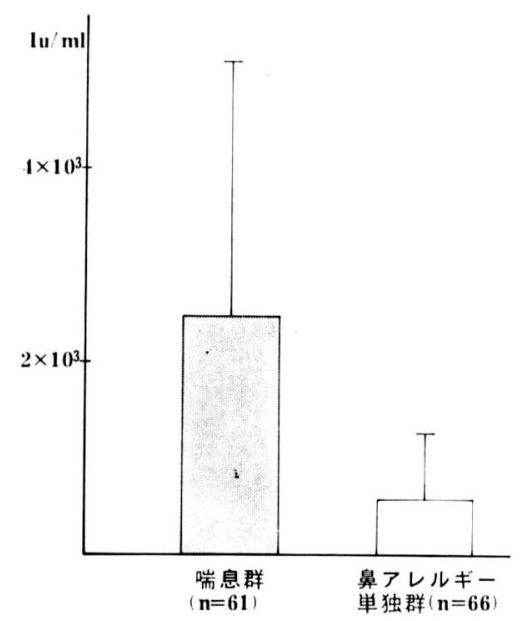

図 9 血清 $\mathrm{IgE}$ 值

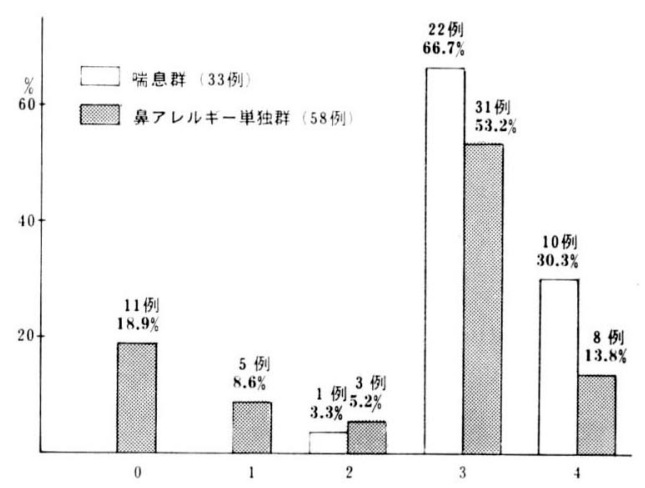

図10 RAST SCORE

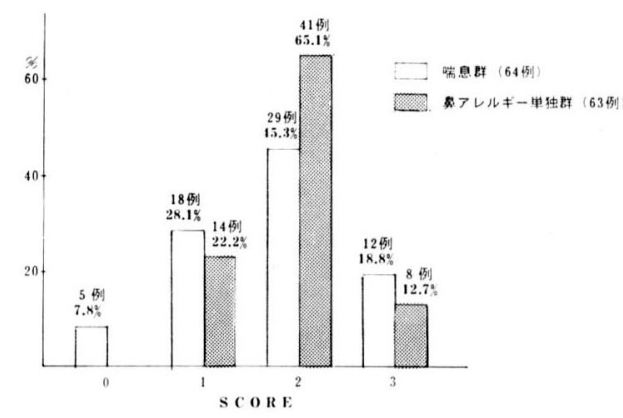

図11 鼻内局所所見



図12 鼻 症 状 
点が最も多く次いで 1 点, 3 点の順であった 鼻症状に怙いては図12に示す如く，喘息群では 0 点又は 1 点が $96.8 \%$ を占めるのに対し鼻アレ

考

鼻内所見や鼻症状の総合的な程度を表現する 方法として我々は $0 ， 1 ， 2 ， 3$ の 4 段階の SCORE を用いた。即ち奥田が分類した鼻の各 症状や各所見の（H）以上に 1 点を与えこれら の合計点で表現した。この方法では（十）が全 く考慮されていない点と（什）又は（州）がい ずれも SCORE 1 とされているので，中等度 症例と高度症例とを区別出来ない欠点がある. しかし中等度以上の症例の総合的な程度を知る 上では簡便な方法であると云える。一方奥田が 分類した各鼻症状の程度，各鼻粘膜所見の程度 の $(+),(H),(H)$ にそれぞれ $1 ， 2 ， 3$ 点 を与えこれらの合計点で総合的な程度を表現す る方法は，一般的によく用いられており，我々 が用いた方法よりもより正確に表現することが 出来る。しかし表現された SCORE からそれ ぞれの症状や所見の程度を推测するにはより複 雑である.

さて皮内反応，鼻粘膜誘発反忘，鼻汁好酸球 検查，鼻内局所所見， RAST SCORE 等から 我々が対象とした外因性の小児喘息患者の約 60\%は鼻アレルギーを令併していろことが分っ た。そしてこ礼らの患者の鼻内局所所見や隠床 検查成績は鼻アレルギー単独群のそ机とほとん ぞ差のないことも分った。しかし鼻症状に拀い ては著るしい差を認め, 図12に示した如く鼻ア レルギー群で SCORE 2 又は 3 を示したもの が全体の約 $90 \%$ でったのに対し，喘息群では SCORE 0 又は 1 を示したものが約 $97 \%$ 占め ていた。

奥田 ${ }^{1)}$ によれば鼻症状としてのくしゃみ発作 は抗原粒子が粘液層に沈着した結果, 抗原性物 質が溶出され，好塩基性細胞に働き脱顆粒を起 す.脱顆粒により遊離された chemical mediator が鼻粘膜に分布する三丈神経終末のくしゃ
ルギー群では 2 点以上が $88.8 \%$ と症例の大半を 占めていた。

按

み受容器を刺激し,くしゃみ中枢に伝わり, 呼吸 筫に働いてくしゃみ発作が出現する. 水性鼻汁 の分泌は, 脱顆粒により生じた chemical mediator が分泌腺又は杯細胞に直接働いて分泌充進 がおこる場合と，神経終末を刺激して分泌を促 進する場合とがある。鼻閉はやはり chemical mediator が血管に直接働く場合と，神経を介 して血管に働く場合とがあるが，いずれも末梢 血管の透過性六進による浮腫を生ぜしめ, 血流 障害を併発し粘膜の腫脹を来し鼻閉が生ずる。 このように鼻症状を誘発する因子はいずれも好 塩基性細胞から遊離される chemical mediator の直接又は間接的な働きによって生ずる.

我々が検討している鼻アレルギーを合併した 小児喘息患者においては, 鼻症状をほとんど認 めなかったが，これらの患者の鼻汁から好酸球 增多を証明することができ，更に特異抗原によ る鼻粘膜誘発試験を行らと容易に鼻症状を誘発 することが出来た. 以上のことより鼻症状がな くても，鼻粘膜上又は粘膜内において，抗原浸 入の結果, 好塩基性細胞から chemical mediator が遊離していることは確実であり, ある閾值以 上の抗原が鼻粘膜に作用するか，好塩基性細胞 から遊離される chemical mediator の濃度があ る閾値以上になれば容易に鼻症状を誘発させる ことが可能であることを示している，そして chemical mediator が存在するにもかかわらず, 鼻症状を呈さないのは鼻粘膜の chemical mediator に対する反応性の違い又は好塩基性細胞 から遊離される chemical mediator の濃度の 違いから来ているのか子分らない.

我々の検討した喘息群では鼻症状がほとんど ないのにもかかわらず，鼻粘膜局所所見におい て鼻アレルギー特有の下甲介粘膜蒼白, 腫脹, 水性分泌物の立進等が垫められたことに関して 
いささか矛盾を感ずる。しかしハウスダストの ような非季節性抗原に長期曝露をらけると, 下 甲介粘膜の浮腫状肥厚や充血等の循環障害を伴 った不可逆的組織变化をみることがしばしばで ある. 更に粘膜表面が長期にわたり抗原に曝露 されると不可逆性の杯細胞の增加や腺の腫大を 来たすことがしばしばである ${ }^{12)}$. 以上のような 抗原刺激による不可逆性の変化により鼻症状と 局所所見は相関しないのであろら。

小児喘息患者における皮内反応について，八 ウスダストの陽性率は馬場 ${ }^{13)} 70.3 \%$ ，吉田 $ら^{1)} 73.2 \%$ ，林ら ${ }^{2)} 87.6 \%$ と我々の $90.8 \%$ より幾 分低い傾向にあった。ハウスダストによる鼻粘 膜の誘発試験陽性率 $67.7 \%$ は吉田ら ${ }^{11}$ の報告し た $65.9 \%$ とほぼ類似していた。

喘息患者に打ける鼻汁中好酸球增多を示寸割 合は50〜80\%まで23)14) 16)報告者によりまちま ちであるが，我々の成績 $(44.6 \%)$ は林 ${ }^{2)}$ の 48.5 \%より低值を示した。

小児喘息に鼻アレルギーを合併する割合は我 々の症例では $60 \%$ に認めたが，奥田 ${ }^{3)}$ は $75.0 \%$, 水谷 ${ }^{4} 50 \%$, 吉田ら ${ }^{1)} 80 \%$ と施設によりか度り差 があるように思える。

我々の症例において鼻アレルギー単独群との
間に有意差を認めた血中の好酸球数は $\mathrm{My}$ gind $^{17)}$ によれば， shock organ の大きさを反映 しており，鼻アレルギー単独群よりも鼻アレル ギーを合併した喘息群の方がより高值を示すと 云っている.

血清 $\operatorname{IgE}$ 值は喘息群と鼻アレルギー群との 間に著るしい差を示した。そして喘息群の $\operatorname{IgE}$ 值が著るしく高值を示した原因として，我々が 対象とした症例の 1 秒率は $68 \%$ と正常值より著 るしく悪く，従ってほとんどが入院治療の必要 な重症例を対象にしたことによるのかも分らな い.

最後に小児喘息患者の副鼻腔，特に上顎洞に ついて鼻部レ線写真 ${ }^{18)}$ (Waters 法) から両側 上顎洞がびまん性に混濁を認めたのは $40 \%$ と最 も高く, 中等度の $27.5 \%$ 合わせると $67.5 \%$ が 中等度以上上顎洞に陰影を認めたことになる。 これに関し吉田ら ${ }^{1)} 62.5 \%$ ，松村 ${ }^{16)} 48.8 \%$ の 報告がある．さらに鼻汁中好中球数が中等度以 上即ち1000倍の視野で20個以上を認めたのは $53.1 \%$ ，そして好中球增多を示した鼻汁中には 多数の細菌を証明しえたこと等から我々が対象 とした小児喘息患者の少くとも半数には上顎洞 炎を合併しているものと考えられる。

\section{ま と め}

国立三重病院小児医療センターでアトピー型又は混合型気管支喘息と診断された 5 才から18才ま での65名を対象とし鼻症状, 鼻粘膜局所所見, 鼻汁検査, 鼻粘膜誘発試験, 鼻部レ線検査, 血中好 酸球, 血清 IgE, RAST, 皮内反応閾值試験, 肺機能検査等を行った。そしてこれらの検查所見を ハウスダスト小児鼻アレルギー群のそれと比較検討し次の結果を得た。

1. 喘息群の 1 秒率は67.9\% $22.0(\mathrm{n}=65)$ と正常値の $80 \%$ に比べ著るしく低值を示した.

2. 喘息群の皮内反応による抗原陽性率は八ウスダストが $90.8 \%$ と最も多く次いでパスパート $78.5 \%$ ，ブロンカスマ52.3\%の順であった，又ほとんどの症例で重複抗原に陽性であった。

3. 喘息群の鼻汁中好酸球増多は $44.6 \%$ 見られた。

4. 喘息群のハウスダストによる鼻粘膜誘発試験は $67.7 \%$ 陽性であった.

5. 皮内反忘, 鼻汁中好酸球, 鼻粘膜誘発試験, 既往歴等から喘息単独 $30.8 \%$, 喘息にアトピー 性皮膚炎を合併したもの $9.2 \%$ ，喘息に鼻アレルギーを合併したもの $40 \% ，$ 喘息に鼻アレルギーと アトピー性皮膚炎を合併したもの $20 \%$ であった。

6. 喘息群の鼻部レ線検査の結果，両側上顎洞のびをん性混濁は $40 \%$ に認められた。

7. 喘息群の鼻汁中好中球増多（1000倍の視野で20個以上）は53.1\%であった。 
8. 血中好酸球数は喘息群で $800.8 / \mathrm{mm}^{3} \pm 559.4(\mathrm{n}=62)$, 鼻アレルギー単独群 $616 / \mathrm{mm}^{3} \pm 400$ $(\mathrm{n}=60)$ で有意差を認めた（ $\mathrm{p}<0.05 ）$.

9. 血清 $\operatorname{IgE}$ 值は, 喘息群 $2474.8 \mathrm{IU} / \mathrm{ml} \pm 2640(\mathrm{n}=61)$, 鼻アレルギー単独群 $569.6 \mathrm{IU} / \mathrm{ml} \pm$ $670.5(\mathrm{n}=66)$ で有意差を認めた $(\mathrm{p}<0.001)$.

10. 皮内反応閾値や RAST SCORE は喘息群，鼻アレルギー単独群とも同様な傾向を示した.

11. 鼻内局所所見では，喘息群は鼻アレルギー単独群と同様な所見を認めたが，鼻症状において は，鼻アレルギー群に比べ中等度以上の症状を訴えることはほとんどなかった。

12. 喘息群で鼻症状を自覚しないのは，鼻粘膜の chemical mediator に対する反応性の低下， あるいは遊離される chemical mediator が低濃度であるためではないかと推論した。

本論文の要旨は第81回日耳鼻総会（昭和55年 4 月10日）においてロ演した.

\section{参 考 文 献}

1）吉田 亮, 他 : 気管支喘息患者の鼻所見並びに鼻 粘膜誘発試験について，小児科臨床 $21: 644 \sim$ $648,1968$.

2）林 鷹治, 他：アレルギー性鼻炎の実態・小児喘 息との関連に於ける考察. 耳鼻臨床 $60: 1087$ 1100, 1967.

3）奥田 稔：鼻アレルギーと気管支喘息. 気食会報 $27: 54 \sim 59,1976$.

4）水谷 明, 他：東海地方における気管支喘息の臨 床統計的観察. アレルギー $22: 329 \sim 340,1973$.

5）黑住静之, 他: 気道アレルギーにおける上気道・ 下気道調節機構に関する考察. アレルギー 21 ： 441 456, 1972.

6）石崎 達, 他 : 気管支喘息の分類 : 鼻型, 気管支 型の差異に就て・アレルギー $11: 284 \sim 289,1962$.

7）寺尾 彬, 佐藤靖雄 : アレルギー性鼻炎と気管支 喘息. 内科 $15: 869 \sim 874,1965$.

8) Broder I, et al : The epidemiology of asthma and hay fever in a total community, Tecumseh, Michigan. II. The relationship between asthma and hay fever. J Allergy $33: 524 \sim 531,1962$.

9）鵜飼幸太郎, 他：鼻アレルギー減感作治療に打け る喘息の影響. 耳鼻臨床 $73: 1175 \sim 1185,1980$.

10）奥田 稔: 鼻アレルギー診療の実際一気道アレル
ギーをどう考え，どら治療するか一 p. 89, 東京, 金原出版, 1976.

11）奥田 稔: 気道アレルギー一発症機序一. 気食会 報 $27: 385 \sim 392,1976$.

12）奥田 稔：鼻アレルギーの基礎と臨床.耳鼻 20 : 297 344, 1974.

13）馬場 実: 小児科領域におけ気氛道アレルギー性 疾患の治療一とくに小児喘息を中心にして一. 耳 喉 $45: 835 \sim 841,1973$.

14）石倉武雄, 米山亥盛 : 気管支喘息患者の鼻腔所見 に就いて。 日耳鼻 $58: 152,1955$.

15）市原正雄：気管支喘息患者の鼻腔所見について. 日耳鼻 $59: 1471 \sim 1473 ， 1956$.

16）松村龍雄, 他：小児気管支喘息の臨床検査成績. その 1. 血液像, 循環好酸球数, 赤沈, 副鼻腔レ 線所見, 鼻汁・喀疢内好酸球出現率, その他につ いて. アレルギー 14:376〜387, 1965.

17) Mygind $N$ : Nasal Allergy, 1 st ed. Chapter II, Oxford, Blackwell Scientific Publications, 1978.

18）長船宏隆, 他 : 小児副鼻腔炎のレ線学的䛦断につ いて. 耳展 $23: 43 \sim 53,1980$.

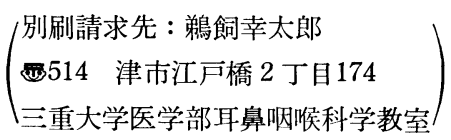

